\title{
PENGARUH TINGKAT SUKU BUNGA TERHADAP SIMPANAN MUDHARABAH PADA BANK UMUM SYARIAH DI INDONESIA
}

\author{
*(Yunni Rusmawati Dj \\ Prodi Manajemen, Fakultas Ekonomi, Universitas Islam Lamongan \\ $\mathrm{Jl}$. Veteran No.53A Lamongan \\ Telp. ( 0322 ) 324706, Faks. ( 0322 ) 324706 \\ Email:jpim.unisla@gmail.com
}

\begin{abstract}
ABSTRAK
Sektor perbankan merupakan urat nadi bagi sektor keuangan mengingat fungsinya sebagai lembaga intermediasi antara pihak yang kekurangan dana dengan yang kelebihan dana. Dana bank terbesar bersumber dari masyarakat atau biasa disebut dana pihak ketiga (DPK). DPK pada bank syariah lebih didominasi oleh simpanan mudharabah yang terdiri dari deposito dan tabungan mudharabah mengingat pada simpanan mudharabah terdapat bagi hasil yang diberikan kepada nasabah. Pertumbuhan simpanan mudharabah pada bank umum syariah di Indonesia cenderung mengalami peningkatan. Hal tersebut diduga dipengaruhi oleh suku bunga.Populasi dalam penelitian ini adalah semua bank umum syariah di Indonesia sedangkan sampel yang diambil adalah laporan keuangan Bank Muamalat Indonesia, Bank Mandiri Syariah dan Bank Mega Syariah. Metode pengumpulan data yang digunakan adalah metode dokumentasi. Teknik analisis data menggunakan analisis regresi linier sederhana. Data penelitian adalah data runtut waktu (time series) tahunan dari tahun 2010 hingga tahun 2015. Hasil dari analisis data menunjukkan bahwa suku bunga memiliki pengaruh yang negatif sebesar 40,4\% yang dapat dilihat pada koefisien determinasi atau $R$ Square sebesar 0,404, sedangkan 59,6\% sisanya dipengaruhi oleh faktor lain.
\end{abstract}

Kata Kunci : Suku bunga dan simpanan mudharabah.

\section{PENDAHULUAN}

Bank mempunyai hubungan
dengan masalah usahar yang
merupakan alat pelancar terjadinya
perdagangan yang utama. Kaitan
antara bank dengan uang dalam suatu
unit bisnis adalah penting, namun di
dalam pelaksanaannya harus
menghilangkan adanya ketidakadilan,
ketidakjujuran dan penghisapan dari
satu pihak ke pihak lain. Oleh karena
itu, untuk menghindari pengoperasian
bank dengan sistem bunga maka Islam
memperkenalkan prinsip muamalah
yaitu melalui sistem bagi hasil. Dengan
kata lain, bank Islam lahir sebagai
salah satu solusi alternatif terhadap

persoalan pertentangan antara bunga bank dengan riba.

Pada umumnya yang dimaksud dengan bank syari'ah adalah lembaga keuangan yang usaha pokoknya memberikan kredit dan jasa-jasa lain dalam lalu lintas pembayaran serta peredaran uang yang beroperasi disesuaikan dengan prinsip-prinsip syari'ah. Tingkat bunga merupakan salah satu pertimbangan seseorang untuk menabung atau mendepositokan dananya pada bank. Tingkat bunga yang tinggi akan mendorong seseorang untuk menabung atau mendepositokan dananya dan mengorbankan konsumsi sekarang untuk dimanfaatkan dimasa yang akan datang (Ghafur, 2003:80). 
Dari uraian sebelumnya mengenai penabung atau deposan yang dominan mencari keuntungan adalah dilihat dari segi tingkat suku bunga bank konvensional, jika tingkat suku bunga lebih tinggi dari tingkat bagi hasil maka nasabah memilih untuk menyimpan dananya di bank konvensional dan sebaliknya jika tingkat bagi hasil lebih besar dari tingkat suku bunga maka nasabah memilih untuk menyimpan dananya di bank syariah (Raditiya, 2007:35). Menurut Haron (2005:67) suku bunga berpengaruh negatif terhadap dana yang dihimpun oleh Bank Islam di Malaysia. Semakin besar tingkat bunga pada bank konvensional maka semakin kecil dana yang dihimpun oleh bank Islam. Sedangkan Ghafur (2003:92) mengungkapkan bahwa suku bunga tidak berpengaruh signifikan terhadap simpanan mudharabah di Bank Muamalat Indonesia.

\section{LANDASAN TEORI}

\section{Konsep Bank Syariah}

Menurut Peraturan Bank Indonesia nomor 2/8/PBI/2000 pasal 1: Bank syariah adalah bank umum (sebagaimana yang dimaksud dalam Undang-Undang nomor 7 / 1992 tentang perbankan dan telah diubah dengan Undang-Undang nomor 10 / 1998) yang melakukan kegiatan usaha berdasarkan prinsip syariah termasuk unit usaha syariah dan kantor cabang bank asing yang melakukan kegiatan usaha berdasarkan prinsip syariah. Bank Islam atau selanjutnya disebut bank syari'ah adalah bank yang beroperasi dengan tidak mengandalkan pada bunga (Muhammad, 2005:13).

Menurut PSAK no. 105 paragraf 4 Al Mudharabah terbagi atas tiga jenis, pertama mudharabah muthlaqah adalah mudharabah dimana pemilik dana memberikan kebebasan kepada pengelola dana dalam pengelolaan investasinya, kedua mudharabah muqayyadah adalah mudharabah dimana pemilik dana memberikan batasan kepada pengelola dana, antara lain mengenai tempat, cara dan/atau objek investasi, ketiga mudharabah musytarakah adalah bentuk mudharabah dimana pengelola dana menyertakan modal atau dananya dalam kerja sama investasi.

\section{Teori Tingkat Bunga}

Teori Klasik Tentang Tingkat Bunga Menurut teori klasik tabungan adalah fungsi dari tingkat bunga. Makin tinggi tingkat bunga makin tinggi pula keinginan masyarakat untuk menabung. Artinya, pada tingkat bunga yang lebih tinggi masyarakat akan terdorong untuk mengorbankan / mengurangi pengeluaran untuk konsumsi guna menambah tabungan (Nopirin, 2000:70-71).

\section{Pengaruh Suku Bunga Terhadap Simpanan Mudharabah}

Bank syariah merupakan bank yang tidak mengandalkan pada bunga. Dalam menghadapi persaingan dengan bank konvensional untuk menghimpun dana dari masyarakat, maka tingkat bunga bank konvensional menjadi suatu pertimbangan bagi bank syariah. Tingkat suku bunga disini digunakan sebagai pembanding terhadap bagi hasil pada bank syariah, apakah masyarakat Indonesia terpengaruh terhadap besarnya tingkat bunga atau tidak dalam menyimpan uangnya di bank syariah. Jika masyarakat Indonesia dalam menyimpan uangnya berdasarkan profit motif maka apabila tingkat suku bunga bank konvensional lebih besar dibandingkan tingkat bagi hasil pada bank syariah, masyarakat akan lebih memilih menyimpan uangnya di bank konvensional yang memberikan return yang lebih tinggi.

Argumen ini diperkuat dengan penelitian yang dilakukan oleh Ahmad dan Haron (2000) yang menyatakan bahwa suku bunga bank konvensional 
memiliki pengaruh negatif terhadap dana yang dihimpun oleh bank Islam di Malaysia. Artinya semakin besar suku bunga bank konvensional maka semakin kecil dana yang mampu dihimpun oleh bank Islam.

Penelitian ini didukung oleh

penelitian Fitriyah tahun 2009 "Pengaruh inflasi, PDB riil, tingkat suku bunga dan bagi hasil terhadap deposito mudharabah pada PT. Bank Muamalat Indonesia". Mengungkapkan bahwa inflasi dan PDB riil berpengaruh positif dan signifikan terhadap deposito mudharabah, sedangkan bagi hasil berpengaruh positif tetapi tidak signifikan. Variabel suku bunga berpengaruh negatif dan signifikan terhadap deposito mudharabah.

\section{Penelitian Terdahulu}

Hal yang sama dikemukakan oleh Haron dan Ahmad dari penelitian yang berjudul "The Effects of Conventional Interest Rates and Rate of Profit on Funds Deposited With Islamic Banking System in Malaysia" tahun 2000 yang menyimpulkan bahwa suku bunga berpengaruh negatif dan bagi hasil be Penelitian oleh Raditiya tahun 2007 "Pengaruh Tingkat Suku Bunga dan Bagi Hasil terhadap Deposito Mudharabah" yang menemukan hasil yang sama dengan penelitian yang dilakukan oleh Indrawan. Hasil penelitiannya mengungkapkan bahwa Bagi Hasil tidak mempengaruhi deposito mudharabah di Bank Syariah Mandiri sedangkan suku bunga berpengaruh negatif terhadap deposito mudharabah.

\section{Hipotesis}

Hipotesis merupakan jawaban sementara terhadap rumusan masalah karena sifatnya sementara, maka perlu dibuktikan kebenarannya melalui data empirik yang terkumpul. Hipotesis yang akan dikemukakan penulis adalah bahwa:
Ha : Ada pengaruh yang signifikan antara tingkat suku bunga terhadap simpanan mudharabah pada bank umum syariah di Indonesia.

Ho : Tidak ada pengaruh yang signifikan antara tingkat suku bunga terhadap simpanan Mudharabah pada bank umum syariah di Indonesia.

\section{Deskripsi Populasi dan Penentuan Sampel}

Populasi di definisikan sebagai keseluruhan subyek penelitian (Arikunto, 2006:130). Adapun populasi dalam penelitian ini adalah bank umum syariah di Indonesia yang terdiri dari 11 Bank Muamalat Indonesia, Bank Syariah Mandiri, Bank Mega Syariah, Bank Syariah Syariah BRI, Bank Syariah Bukopin, Bank Panin Syariah, Bank Victoria Syariah, BCA Syariah, Bank Jabar dan Banten, Bank Syariah BNI, serta May Bank Indonesia Syariah. Sampel adalah sebagian atau wakil populasi yang diteliti (Arikunto, 2006: 131). Pengambilan sampel dari populasi dilakukan secara purpose sampling, yaitu menentukan sampel dengan pertimbangan tertentu yang dipandang dapat memberikan data secara maksimal (Arikunto, 2006:16). Dari kriteria tersebut maka sampel yang diambil adalah laporan keuangan pada Bank Syariah Muamalat, Bank Syariah Mandiri, Bank Syariah Mega Indonesia periode 2010-2015.

\section{Variabel Penelitian dan Definisi Operasional}

Variabel terikat / dependent (Y), yaitu variabel yang dipengaruhi atau yang menjadi akibat karena adanya variabel bebas (X). Variabel terikat (Y) yang digunakan adalam penelitian adalah simpanan mudharabah. 
Variabel bebas / independent (X), yaitu variabel yang menjadi sebab timbulnya atau berubahnya variabel terikat. Variabel bebas (X) yang digunakan dalam penelitian ini adalah tingkat suku bunga.

Definisi operasional dari masingmasing variabel adalah sebagai berikut:

\section{Simpanan mudharabah (Y)}

Simpanan mudharabah adalah jenis sumber dana bagi bank syariah yang berasal dari masyarakat. Simpanan mudharabah terdiri dari tabungan dan deposito mudharabah. Simpanan mudharabah pada Bank Syariah Muamalat, Bank Syariah Mandiri, Bank Syariah Mega Indonesia yang digunakan dalam penelitian ini adalah simpanan yang berasal dari pihak ketiga bukan bank. Data simpanan mudharabah berbentuk data tahunan yaitu data pada periode tahun 2010 sampai tahun 2015 yang dinyatakan dalam satuan jutaan rupiah.

\section{Suku bunga $(\mathrm{X})$}

Tingkat suku bunga mencerminkan biaya yang diperoleh karena meminjam sejumlah dana serta pendapatan yang diperoleh karena telah meminjam dana tersebut. Suku bunga yang digunakan dalam penelitian adalah suku bunga deposito bank umum berjangka 3 bulan. Data suku bunga deposito berbentuk data tahunan mulai periode tahun 2010 hingga tahun 2015 yang dinyatakan dalam satuan persen.

\section{Teknik Pengumpulan Data}

Pengumpulan data dilakukan dengan metode dokumentasi yaitu mengumpulkan data sekunder mengenai variabel penelitian. Data penelitian yang terdiri dari data tentang suku bunga, inflasi, jumlah uang beredar, bagi hasil serta simpanan mudharabah dikumpulkan dengan cara dicatat, didownload dan difotokopi. Data yang telah dikumpulkan kemudian diolah kembali agar sesuai dengan data yang dimaksud dalam penelitian.

\section{Teknik Analisis Data}

Data yang terkumpul selanjutnya akan diperoleh dan dianalisis untuk dapat menjawab permasalahan dalam penelitian dengan menggunakan :

\section{Analisis Deskriptif}

Teknik analisis deskriptif digunakan untuk menjelaskan atau mendeskripsikan perkembangan variabel-variabel penelitian, yaitu simpanan mudharabah pada Bank Muamalat Indonesia, Bank Syariah Mandiri, dan Bank Syariah Mega Indonesia.

Analisis Statistik

Uji Normalitas

Uji signifikansi pengaruh variabel independen terhadap variabel dependen melalui uji $\mathrm{t}$ hanya akan valid jika residual yang kita dapatkan mempunyai distribusi normal. Histogram residual merupakan metode grafis yang paling sederhana digunakan untuk mengetahui apakah bentuk dari Probability Distribution Function (PDF) dari variabel random berbentuk distribusi normal atau tidak. Jika histogram residual menyerupai grafik distribusi normal maka bisa dikatakan bahwa residual mempunyai distribusi normal. Bentuk grafik distribusi normal ini menyerupai lonceng seperti distribusi t dimana jika grafik distribusi normal tersebut dibagi dua akan mempunyai bagian yang sama. (Sugiyono, 2010:86)

Analisis Regresi sederhana

Untuk mengetahui pengaruh dari suku bunga terhadap simpanan mudharabah pada Bank Syariah Muamalat, Bank Syariah Mandiri, 
Bank Syariah Mega Indonesia. Adapun teknik analisis data yang digunakan oleh penulis adalah sebagai berikut :

$$
\mathrm{Y}=\mathrm{a}+\mathrm{bX}
$$

(Sugiyono, 2010:188)

Keterangan :

$\mathrm{Y}=$ Variabel terikat (Simpanan Mudharabah)

$\mathrm{a}=$ Konstanta

$\mathrm{b}=$ Koefisien regresi

$\mathrm{X}=$ Variabel bebas (Suku Bunga)

Pengujian hipotesis (t-test)

Uji t-test ini digunakan untuk mengetahui besarnya pengaruh masing-masing variabel independen (tingkat suku bunga) terhadap variabel dependen (simpanan mudharabah) dengan tingkat signifikan 5\% $(\cos =0,05)$.

$$
t=\frac{r \sqrt{n-2}}{\sqrt{1-y^{2}}}
$$

(Sugiyono, 2010:78)

Keterangan :

$$
\begin{aligned}
& \mathrm{t}=\text { nilai uji } \mathrm{t} \\
& \mathrm{n}=\text { jumlah responden yang teliti }
\end{aligned}
$$

Koefisien determinasi $\left(\mathrm{R}^{2}\right)$

Pengujian ini digunakan untuk mengetahui besarnya variabel bebas (tingkat suku bunga) dihitung koefisien determinan korelasi. Rumus determinan korelasi $\left(\mathrm{R}^{2}\right)$ dapat digunakan adalah sebagai berikut :

$$
\mathrm{R}^{2}=\quad \frac{\text { Jumlah kuadrat regresi }}{\text { Jumlah kuadrat total }}
$$

(Sugiyono, 2010:81)
Seluruh penghitung pengujian di atas menggunakan bantuan komputer program SPSS for windows versi 17.0

\section{PEMBAHASAN}

\section{Hasil Analisis}

Uji t akan valid jika residual yang kita dapatkan berdistribusi normal. Dalam pembahasan ini dilakukan dengan cara histogram residual. Salah satu cara termudah untuk melihat normalitas residual adalah dengan melihat grafik histogram yang membandingkan antara data observasi dengan distribusi yang mendekati distribusi normal. Jika histogram residual menyerupai grafik distribusi normal yaitu menyerupai lonceng seperti distribusi $\mathrm{t}$ bisa dikatakan bahwa residual mempunyai distribusi normal.

\section{Gambar 1.}

\section{Gambar Histogram Residual}

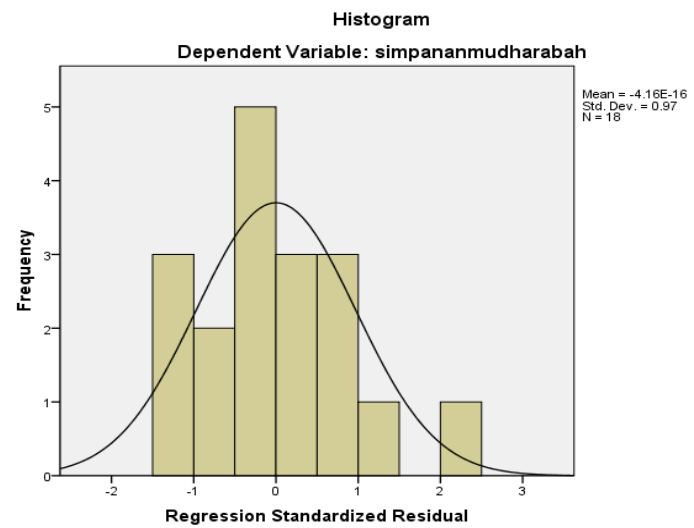

Dari hasil di atas terlihat bahwa histogram residual memiliki bentuk seperti distribusi $\mathrm{t}$ dimana jika grafik distribusi normal tersebut dibagi dua akan menghasilkan bagian yang sama sehingga dapat disimpulkan bahwa residual berdistribusi normal.

\section{Uji Hipotesis}

Perhitungan dilakukan dengan menggunakan analisis regresi linier sederhana dengan variabel bebas (X) suku bunga dan variabel terikat (Y) 
simpanan mudharabah, dengan bantuan program komputer SPSS 17 windows. Adapun hasil perhitungan tersebut diringkas sebagai berikut

Tabel 1.

\section{Hasil Perhitungan Regresi Linier Sederhana}

\begin{tabular}{|l|l|l|l|}
\hline Variabel & $\begin{array}{l}\text { Koefisien } \\
\text { Reg }\end{array}$ & $\begin{array}{l}\text { T } \\
\text { hitung }\end{array}$ & Sig. \\
\hline $\begin{array}{l}\text { Suku } \\
\text { Bunga }\end{array}$ & $\begin{array}{l}\text { 2111226,896 } \\
\text { Konstanta }\end{array}$ & $-\mathbf{1 , 7 6 5}$ & $\mathbf{0 , 0 9 7}$ \\
\hline R 2 = 0,163 & $\mathbf{2 , 5 6}$ & $\mathbf{2 5 4 0}$ & $\mathbf{0 , 0 2 2}$ \\
R = 0, 404 \\
Sig = 0,022 \\
N = 18 \\
\hline
\end{tabular}

Sumber : Hasil Perolehan Data

Perhitungan SPSS Versi 17.0

Dari hasil perhitungan regresi

sederhana pada tabel4.1 di dapat persamaan regresi sederhana sebagai berikut :

$$
Y=2,56+(-2111226,896) X
$$

Keterangan :

$$
\begin{aligned}
& Y=\text { Simpanan Mudharabah } \\
& X=\text { Suku Bunga }
\end{aligned}
$$

Koefisien regresi untuk variabel suku bunga sebesar 2111226,896 dan tidak mempunyai pengaruh signifikan terhadap besarnya simpanan mudharabah pada Bank Umum Syariah. Suku bunga yang tidak mempunyai pengaruh signifikan ditunjukkan oleh nilai probabilitas yang lebih besar dari 0,05 yaitu sebesar 0,097. Dilihat dari arah hubungan antara suku bunga dan simpanan mudharabah menunjukkan hubungan yang negatif

Melihat hasil persamaan regresi di atas menunjukkan tidak berpengaruhnya suku bunga terhadap simpanan mudharabah pada bank umum syariah di Indonesia.

Nilai R atau koefisien korelasi menunjukkan seberapa kuat hubungan antara variabel bebas dengan variabel terikatnya. Dari hasil perhitungan diketahui bahwa terjadi hubungan atau korelasi yang sedang sebesar 0,404 atau 40,4\% antara suku bunga dengan simpanan mudharabah.

Variabel suku bunga dari tabel tersebut diatas dapat dilihat bahwa nilai p-value $0,000<0,05$ artinya signifikan sedangkan t-hitung $-1,765$ $>1,743$ atau lebih kecil dari $t$ tabel $(\mathrm{t}$ hitung $<\mathrm{t}$ tabel ), sehingga Ho diterima yang berarti bahwa suku bunga deposito berjangka 3 bulan tidak berpengaruh secara signifikan terhadap simpanan mudharabah pada bank umum syariah.

\section{Interprestasi}

Suku bunga deposito tidak signifikan terhadap simpanan mudharabah. Tetapi jika dilihat arah hubungannya yaitu negatif, artinya jika terjadi peningkatan suku bunga deposito berjangka 3 bulan bank konvensional maka simpanan mudharabah pada bank umum syariah akan menurun.

Hasil regresi yang menunjukkan tidak berpengaruhnya suku bunga terhadap simpanan mudharabah pada bank umum syariah di Indonesia adalah karena lebih dominannya faktor kepercayaan masyarakat terhadap keunggulan bank umum syariah dengan sistem bagi hasilnya dimana bank syariah tidak mengandalkan pada tingkat bunga yang cenderung terpengaruh dengan keadaan ekonomi Indonesia yang selalu berubah-ubah. Masyarakat menganggap bahwa bank umum syariah merupakan solusi yang aman dalam menyimpan dana karena meskipun keadaan ekonomi parah 
bank syariah tetap mampu mempertahankan eksistensinya ini dibuktikan pada saat terjadi krisis moneter banyak bank konvensional yang tidak mampu menjaga likuiditasnya tetapi Bank Muamalat Indonesia sebagai satu-satunya bank syariah tidak terpengaruh sama sekali dengan gonjang-ganjing perekonomian pada saat itu (Suhrawardi, 2010).

Faktor lain yang mempengaruhi peningkatan simpanan mudharabah adalah karena adanya fatwa haram bunga bank dari MUI tahun 2004, sehingga masyarakat lebih terdorong untuk meninggalkan keuntungan dari tingkat bunga dan lebih mengutamakan menjalankan syariat Islam (www.infobanknews.com). Selain itu juga adanya asas keadilan yang ditunjukkan melalui pembagian bagi hasil sesuai dengan pendapatan bank syariah.

Jika dilihat dari arah hubungannya yaitu negatif, maka jika tingkat suku bunga yang ditawarkan tinggi dan nasabah tersebut lebih mengutamakan profit motif serta bukan merupakan nasabah loyal maka akan terjadi pengalihan dana ke bank konvensional yang lebih memberikan keuntungan yang pasti dengan angka yang besar.

\section{KESIMPULAN DAN SARAN Kesimpulan}

Penelitian ini bertujuan untuk mengetahui pengaruh variabel tingkat suku bunga terhadap simpanan mudharabah pada bank umum syariah di Indonesia. Hasil penelitian mengungkapkan bahwa Tingkat suku bunga deposito berjangka 3 bulan tidak berpengaruh terhadap besarnya simpanan mudharabah pada bank umum syariah di Indonesia. Peningkatan simpanan mudharabah pada bank umum syariah lebih dikarenakan faktor kepercayaan masyarakat kepada bank umum syariah dimana bank syariah merupakan bank yang tidak mengandalkan pada bunga yang terpengaruh oleh keadaan perekonomian. Masyarakat lebih aman menyimpan dananya di bank umum syariah jika terjadi goncangan ekonomi yang semakin parah. Faktor lain yaitu karena adanya fatwa MUI yang menyebutkan bahwa bunga bank hukumnya adalah haram.

\section{Saran}

Bagi Pemerintah

a. Diharapkan pemerintah dapat lebih mendukung perkembangan bank syariah di Indonesia baik dukungan secara hukum maupun dukungan langsung, yaitu dengan mempercayakan kepada bank syariah untuk mengelola dana milik pemerintah.

b. Diharapkan pemerintah dapat bekerja sama dengan bank-bank syariah untuk memperkenalkan bank syariah kepada masyarakat Indonesia agar masyarakat dapat memahami dan menerima bank syariah bukan hanya sebagai bank berdasarkan prinsip Isla pi lebih kepada fungsi dan, in bank syariah yang besar dalam perekonomian sehingga keberadaan bank syariah di Indonesia dapat lebih diapresiasi oleh masyarakat dan pada akhirnya dapat berkembang pesat dan dapat menyelamatkan perekonomian bangsa Indonesia melalui prinsip syariah yang telah ditetapkan oleh bank syariah tersebut.

2. Bagi Perbankan

Bank umum syariah lebih mampu meningkatkan kepercayaan masyarakat melalui peningkatan kinerja sehingga pendapatan yang mereka terima lebih besar. Selain itu dibutuhkan peningkatan pemahaman kepada masyarakat 
Indonesia pada umumnya dan masyarakat yang beragama Islam pada khususnya tentang pentingnya mejalankan syariat Islam dalam kegiatan ekonominya. Sehingga bank umum syariah dapat lebih berkembang dan mampu bersaing dengan bank-bank konvensional Bank umum syariah harus meningkatkan tingkat keuntungan yang mampu bersaing dengan suku bunga bank konvensional. Karena sifat profit motive yang masih melekat pada nasabah bank umum syariah. Semakin besar keuntungan dari bagi hasil maka simpanan pada bank umum syariah di Indonesia akan semakin meningkat.

3. Bagi Akademik

Diharapkan penelitian ini dikaji lebih mendalam. Misalnya dengan menambah obyek penelitian pada Unit Usaha Syariah (UUS). Sehingga ruang lingkup penelitian semakin luas.

\section{DAFTAR PUSTAKA}

Arikunto, Suharsimi. 2006. Prosedur Penelitian. Jakarta: Rineka Cipta

Fitriyah, Indatul. 2009. Pengaruh Inflasi, PDB Riil, Tingkat Suku Bunga dan Bagi Hasil Terhadap Deposito Mudharabah pada PT. Bank Muamalat Indonesia. Skripsi tidak diterbitkan. Surabaya: Program Strata 1 Unesa

Ghafur, Muhammad. 2003. Potret Perbankan Syariah Indonesia Terkini.

Yogyakarta: Bina Rohani Islam

Ghozali, Imam. 2005. Analisis Multivariate Dengan Program SPSS. Semarang : Badan Penerbit Universitas Diponegoro

Haron, Sudin dan Ahmad. 2000. The Effects of Conventional
Interest Rates and Rate of Profit on Funds Deposited With Islamic Banking System in Malaysia. International Journal of Islamic Financial Services, (Online), Vol. 1 No. 4, (http://globalwebspot.com), diakses tanggal 2 Maret 2016)

Haron, Sudin dan Norsofiza. 2005. Determinants of Islamic and Conventional Deposits In The Malaysian Banking System. Mangerial Finance, (Online), Vol. 34 No. 9, 2008, (http://www.emeraldinsight.co $\mathrm{m}$, diakses 7 Maret 2016)

Muhammad. 2005. Manajemen Bank Syari'ah. Yogyakarta: UPP AMP YKPN

Nopirin. 2000. Ekonomi Moneter. Yogykarta: BPFE

Raditiya, Asriwijaya. 2007. Pengaruh Tingkat Suku Bunga dan Bagi Hasil terhadap Deposito Mudharabah (Bank Syariah Mandiri), (Online). (http://rac.uii.ac.id, diakses tanggal 10 Maret 2016)

Sudarsono, Heri. 2004. Bank dan Lembaga Keuangan Syari'ah, Yogyakarta: Ekonisia

Sugiyono. 2010. Metode Penelitian Administrasi. Bandung: Alfabeta

Suhrawardi, Lubis. 2010. Mengapa Harus Pilih Perbankan Syariah, (Online), (www.suhrawardilubis.multipl y.com, diakses tanggal 11 Maret 2016)

Sukirno, Sadono. 2003. Pengantar Teori Makro Ekonomi. Jakarta: PT. Raja Grafindo Persada

Sumitro, Warkum. 1996. Asas-Asas Perbankan Islam dan Lembaga-Lembaga Terkait. Jakarta: PT. Raja Grafindo Persada 
Suparmono. 2004. Pengantar Ekonomika Makro. Yogyakarta: UPP AMP YKPN

Tim Penyusun. 2006. Panduan Penulisan Dan Penilaian Skripsi. Surabaya: Universitas Negeri Surabaya

Widarjono, Agus. 2007. Ekonometrika Teori dan Aplikasi. Yogyakarta: Ekonisia

\section{Sumber Dokumen}

Bank Indonesia. 2015. Sejarah Perbankan Syariah, (Online), (http://www.bi.go.id, diakses tanggal 12 Maret 2016)

Bank Indonesia. 2015. Statistik Perbankan Syariah, (Online), (http://www.bi.go.id, diakses tanggal 12 Maret 2016)

Bank Indonesia. 2015. Peraturan Nomor 2/8/PBI/2000, (Online), (http://www.bi.go.id, diakses tanggal 14 Maret 2016)

Bank Indonesia . 2015. Laporan Keuangan Tahunan, (Online), (http://www.syariahmandiri.co. id, diakses tanggal 14 Maret 2016)

Bank Indonesia. 2015. Laporan Keuangan Tahunan, (Online), (http://www.megasyariah.co.id, diakses tanggal 15 Maret 2016)

Bank Indonesia .2015. Laporan Keuangan Publikasi Triwulanan, (Online), (http://www.muamalatbank.co $\mathrm{m}$, diakses tanggal 15 Maret 2016 )

Bank Indonesia. 2015. Laporan Keuangan Bank Umum Syariah, (Online), (http://www.bi.go.id, diakses tanggal 17 Maret 2016)

Bank Indonesia . 2015. Laporan Perkembangan Ekonomi Keuangan Dan Kerjasama Internasional, (Online), (http://www.bi.go.id, diakses tanggal 17 Maret 2016)

Bank Indonesia . 2015. Laporan Kebijakan Moneter, (Online), (http://www.bi.go.id, diakses tanggal 17 Maret 2016)

Bank Indonesia . 2015. Sejarah, Visi dan Misi, Penghargaan Bank Syariah Mandiri, (Online),

(http://www.syariahmandiri.co. id, diakses tanggal 17 Maret 2016)

Bank Indonesia . 2015. Sejarah, Visi dan Misi, Penghargaan Bank Mega Syariah, (Online), (http://www.megasyariah.co.id, diakses tanggal 17 Maret 2016)

Bank Indonesia . 2015. Sejarah, Visi dan Misi, Penghargaan Bank Muamalat Indonesia, (Online),

(http://www.muamalatbank.co $\mathrm{m}$, diakses tanggal 17 Maret 2016)

Bank Indonesia. 2015. Pengaruh Fatwa Bunga Bank Haram, (Online), (www.infobanknews.com, diakses tanggal 18 Maret 2016)

Bank Indonesia . 2015.

Bagaimana Sistem Ekonomi Bank Syariah Islam, (Online), (http://infomanajemen.wordpre ss.com, diakses tanggal 18 Maret 2016) 